Published in final edited form as:

Transfusion. 2019 May ; 59(5): 1644-1647. doi:10.1111/trf.15192.

\title{
CD4+ T-Cell Lymphopenia in Frequent Platelet Donors Who Have Ceased Platelet Donation for at Least 1 Year
}

\author{
Mahboubeh Rahmani ${ }^{1, \dagger}$, Brooke M. Fortin ${ }^{2}$, Nancy Berliner ${ }^{2}$, Nicolas Issa ${ }^{3}$, Donna \\ Neuberg $^{4}$, Richard M. Kaufman ${ }^{5}$, and John M. Gansner ${ }^{2}$ \\ ${ }^{1}$ Division of Hematopathology, Dalhousie University, Halifax, NS, Canada \\ ${ }^{2}$ Hematology Division, Brigham and Women's Hospital, Boston, MA \\ ${ }^{3}$ Division of Infectious Diseases, Brigham and Women's Hospital, Boston, MA \\ ${ }^{4}$ Department of Biostatistics and Computational Biology, Dana-Farber Cancer Institute, Boston, \\ MA \\ ${ }^{5}$ Department of Pathology, Brigham and Women's Hospital, Boston, MA
}

\begin{abstract}
BACKGROUND-We recently discovered that $30 \%$ of current frequent apheresis platelet donors in a study at our donor center had CD4+ counts below 200 cells $/ \mu \mathrm{L}$. How long CD4+ lymphopenia persists after ceasing plateletpheresis is unknown. Whether there are infectious or other complications in former frequent donors that could relate to CD4+ lymphopenia is also unknown.
\end{abstract}

STUDY DESIGN AND METHODS-We mailed a letter to former frequent apheresis platelet donors who had not donated platelets for at least 12 months. Frequent donation was defined as 20 24 plateletpheresis sessions in at least one 365-day period starting in 2011. Donors who expressed interest in the study were contacted to schedule a study visit. Participants in the study provided a blood sample and completed a health questionnaire that included questions about opportunistic infections and malignancies.

RESULTS-Of 50 potential study candidates who were mailed a letter, 15 participated in the study. There were 2 participants with CD4+ counts below 200 cells $/ \mu \mathrm{L}$, one of whom had prior counts that documented a small improvement with cessation of plateletpheresis. 3 participants had counts between 200 and 300 cells/ $\mu \mathrm{L}$. No study participant had a history of an opportunistic infection or a malignancy associated with immune dysregulation.

CONCLUSION-We detected CD4+ lymphopenia in former frequent apheresis platelet donors who had ceased platelet donation for more than 1 year. There was no evidence that the CD4+ lymphopenia predisposes to opportunistic infections or to malignancies associated with immune dysregulation.

${ }^{\dagger}$ Corresponding Author: Mahboubeh Rahmani, Division of Hematopathology, Department of Pathology and Laboratory Medicine, Queen Elizabeth II Health Sciences Centre, Dalhousie University, Halifax, Nova Scotia, Canada, Office: (902) 473 4170, Fax: (902) 473 4113, mahboubeh.rahmani@nshealth.ca. Reprints will not be available from the corresponding author.

The authors declare that they have no conflicts of interest relevant to the manuscript submitted to TRANSFUSION. 


\section{Keywords}

Plateletpheresis; Trima Accel; CD4+ lymphopenia; idiopathic CD4 lymphopenia; lymphocyte depletion; infection; malignancy

Apheresis platelet donors in the United States currently donate up to 24 times in a rolling 12-month period. ${ }^{1}$ In the 1980 s, there was concern that frequent plateletpheresis might cause lymphocyte depletion in donors. ${ }^{2-8}$ However, this concern waned as apheresis technology improved. ${ }^{9}$

We recently studied a group of current platelet donors undergoing plateletpheresis using the Trima Accel Automated Blood Collection System (Terumo BCT, Lakewood, CO). ${ }^{10}$ Plateletpheresis at our donor center has been conducted exclusively with the Trima Accel instrument since 2006. Surprisingly, 6 of 20 current frequent donors (20-24 sessions in the prior 365-day period) had CD4+ T-lymphocyte counts below 200 cells/ $\mu \mathrm{L}$. In addition, 2 of 9 donors who were donating less frequently but had a history of frequent plateletpheresis had CD4+ counts below 200 cells/ $\mu \mathrm{L}$. CD4+ lymphopenia of this degree is generally viewed with concern and is used to define AIDS in the setting of HIV infection; however, the donors were healthy and tested negative for HIV at each donation.

How long CD4+ T-cell lymphopenia persists after stopping plateletpheresis is unknown. Whether there are infectious or other complications that could relate to CD4+ T-cell lymphopenia in former donors is also unknown. We therefore investigated the blood counts (including CD4+ counts) and medical histories of former platelet donors who had a history of frequent platelet donation but had stopped donating platelets for at least 12 months.

\section{MATERIALS AND METHODS}

Approval for the study was obtained from the Partners HealthCare Institutional Review Board (2017P002880). All participants provided written informed consent. We mailed a letter to former frequent apheresis platelet donors who had not donated platelets at our donor center for at least 12 months. Frequent platelet donation was defined as 20-24 successful plateletpheresis sessions in at least one 365-day period starting in 2011. Donors who replied to the letter were contacted by phone to schedule a study visit. Donors who consented to participate in the study confirmed that they had not donated platelets in the prior 12 months, provided a blood sample for analysis, and completed a health questionnaire that included questions about opportunistic infections and malignancies. Medical records of these donors were also reviewed, where available. All study visits were completed between April and July of 2018.

Complete blood counts with white cell differential counts were performed on a hematology analyzer (Sysmex, Lincolnshire, IL). Flow cytometry to obtain lymphocyte subset counts was performed using antibodies to CD3, CD4, CD8, CD16, CD56, and CD19. T-cells were identified as $\mathrm{CD} 3+$ and then divided into $\mathrm{CD} 4+$ and CD8+ populations. Laboratory reference ranges were: $0.72-4.10 \times 10^{3}$ cells $/ \mu \mathrm{L}$ for $1 y m p h o c y t e s, 441-2156$ cells $/ \mu \mathrm{L}$ for CD4+ T-lymphocytes and 125-1312 cells/ $\mu \mathrm{L}$ for CD8+ T-lymphocytes. 
A two-tailed Student's T-test was used for the comparison in Figure 1.

\section{RESULTS}

Of 52 former frequent platelet donors identified as eligible to receive a letter, one was known to have died of a myocardial infarction and another had requested not to receive communications from the donor center. Therefore, 50 potential study candidates were mailed a letter, which included a query asking about recent platelet donation at any center and the reason for ceasing donation at our center. Twelve letters were returned as undeliverable. Twenty-two letters were returned by their recipients, whose query responses are summarized in Table S1. In seven cases, potential study candidates who returned the letter either declined to participate in the study, did not respond when contacted to schedule a study visit, or failed to show up for the study visit. In total, 15 former frequent platelet donors elected to participate in the study.

Select characteristics and blood counts of the 15 study participants are shown in Table 1. The median age was 64 and $40 \%$ of study participants were female. All participants identified as Caucasian. The number of successful plateletpheresis sessions over the 15 years prior to the last donation session ranged from 47 to 330. The types of donations for each study participant (singles, doubles, or triples) over the last 5 years prior to the last donation session (the period for which electronic records were available for all donors) are shown in Figure S2. The most common reason for ceasing platelet donation was a positive HLA antibody test ( 5 participants) followed by "inconvenience" ( 3 participants) and "low white blood cells" as well as "heart trouble" (2 participants each). All former donors had tested negative for HIV while donating platelets. There were 2 participants with CD4+ Tlymphocyte counts below 200 cells $/ \mu \mathrm{L}$ and 3 with CD4+ counts below 300 cells $/ \mu \mathrm{L}$ but above 200 cells/ $\mu \mathrm{L}$ (Table 1 and Figure 1). Overall, the mean CD4+ count was higher in former frequent platelet donors than in current platelet donors with a history of frequent platelet donation studied previously, ${ }^{10} \mathrm{p}=0.0497$ (Figure 1).

One participant with a CD4+ count below 200 cells $/ \mu$ L had prior counts available for review. These showed an improvement in the CD4+ count after cessation of platelet donation one year prior (Figure 2). This participant had undergone functional testing of lymphocytes at the time of a CD4+ count of 130 cells $/ \mu \mathrm{L}$ : lymphocyte proliferation to candida, phytohemagglutinin, and pokeweed were normal; lymphocyte proliferation to tetanus toxoid was reported as "essentially normal." The second participant with a CD4+ count below 200 cells $/ \mu \mathrm{L}$ had ceased platelet donation 2 years prior to participation in the study.

A review of prescription medications and medical problems did not identify an etiology for the low CD4+ T-lymphocyte counts. CD8+ counts were below the reference range in 3 participants (Table 1 and Figure S2), 2 of whom had a CD4+ count between 200 and 300 cells $/ \mu \mathrm{L}$ and one of whom had a CD4+ count between 300 cells $/ \mu \mathrm{L}$ and the lower limit of normal. Other blood counts are shown in Figure S2.

Responses to the health questionnaire showed that no study participant had ever had a severe infection, an infection with an unusual pathogen, or thrush (Table S2). Two former frequent 
platelet donors had a history of shingles (Table S2), both of whom had CD4+ T-lymphocyte counts slightly below the normal range (441-2156 cells $/ \mu \mathrm{L})$ at the time of participation in the study. Six former donors had a history of cancer: Glioblastoma (1 participant), papillary thyroid carcinoma (1 participant), two episodes of squamous cell skin cancer (1 participant), basal cell skin cancer (2 participants), and squamous cell skin cancer as well as melanoma in situ (1 participant) (Table S2). Other responses to the health questionnaire were reassuring and are provided in Table $\mathrm{S} 2$.

\section{DISCUSSION}

In this study of 15 former frequent apheresis platelet donors who had ceased platelet donation for more than 12 months, there were 2 participants with CD4+ counts below 200 cells/ $\mu \mathrm{L}$ and 3 participants with CD4+ counts between 200 and 300 cells $/ \mu \mathrm{L}$.

Plateletpheresis-associated CD4+ T-cell lymphopenia improved slightly in one former frequent platelet donor a year after ceasing plateletpheresis but the CD4+ count remained below 200 cells $/ \mu \mathrm{L}$. Slow improvement in CD4+ counts after cessation of plateletpheresis is also suggested by the fact that mean CD4+ counts were significantly higher in former frequent platelet donors than in current platelet donors with a history of frequent platelet donation studied previously ${ }^{10}$ (Figure 1). We found no evidence that a history of frequent plateletpheresis predisposes to opportunistic infections or to malignancies classically associated with immune dysregulation, even in the setting of CD4+ T-cell lymphopenia.

In our prior study of current apheresis platelet donors, all donors with CD4+ counts under 200 cells $/ \mu \mathrm{L}$ were older than age 55 and had a history of undergoing at least 170 plateletpheresis sessions during the prior 20 -year period. ${ }^{10}$ In the current study, the two donors with a CD4+ count under 200 cells/ $\mu \mathrm{L}$ were also older than age 55 . One donor had a history of 212 successful plateletpheresis sessions during the prior 15-year period and the other had a history of 93 sessions; however, this second donor had a lifetime history of more than 170 sessions.

Given the small number of study participants, it is not possible to discern the relative impact of a number of variables on CD4+ counts: length of time between last plateletpheresis session and assessment of cell counts, age at time of last plateletpheresis session, total number of plateletpheresis sessions, most frequent type of donation (single, double, or triple units), and timing of frequent (20-24 sessions in a 365-day period) donation relative to discontinuation of plateletpheresis.

Frequent plateletpheresis involving a leukoreduction system chamber should be considered in the differential diagnosis of idiopathic CD4+ lymphopenia. This is a heterogeneous clinical syndrome defined as a CD4+ T-lymphocyte count below 300 cells/ $\mu \mathrm{L}$ (or $<20 \%$ of total lymphocytes) on more than one occasion in the absence of an identifiable cause of immunodeficiency. ${ }^{11}$ Whether instruments that do not incorporate a leukoreduction system chamber cause CD4+ T-cell lymphopenia is unknown.

In conclusion, a history of frequent plateletpheresis involving a leukoreduction system chamber can be associated with CD4+ lymphopenia that may persist for more than one year 
after stopping platelet donation. Our current data suggest that plateletpheresis-associated lymphopenia is not harmful to donors. Additional, larger studies are needed to assess the risks, if any, of low CD4+ T-lymphocyte counts in current and former frequent platelet donors.

\title{
Supplementary Material
}

Refer to Web version on PubMed Central for supplementary material.

\section{ACKNOWLEDGMENTS}

\begin{abstract}
We are grateful to the platelet donors for their selfless, anonymous support of patients and for their participation in this study. We thank Rodel Rosales, Jose Menor, Lisa Golemme, Graham Dudley, and Mai Drew for help with flow cytometry. D.N. was supported by a Dana-Farber/Harvard Cancer Center Comprehensive Cancer Center grant from the National Cancer Institute (5P30 CA006516). J.M.G. was supported by a K12 award from the National Heart, Lung, and Blood Institute of the National Institutes of Health (HL087164).
\end{abstract}

J.M.G. was supported by a K12 award from the National Heart, Lung, and Blood Institute of the National Institutes of Health (HL087164). D.N. was supported by a Dana-Farber/Harvard Cancer Center Comprehensive Cancer Center grant from the National Cancer Institute (5P30 CA006516).

\section{REFERENCES}

1. Guidance for Industry and FDA Review Staff: Collection of Platelets by Automated Methods. 2007;

2. Parkman P Revised Guideline for the Collection of Platelets, Pheresis. 1988;

3. Strauss RG. Apheresis donor safety--changes in humoral and cellular immunity. J Clin Apher. 1984;2(1):68-80. [PubMed: 6536660]

4. Koepke JA, Parks WM, Goeken JA, Klee GG, Strauss RG. The safety of weekly plateletpheresis: effect on the donors' lymphocyte population. Transfusion. 1981;21(1):59-63. [PubMed: 6970434]

5. Robbins G, Petersen CV, Brozović B. Lymphocytopenia in donors undergoing regular platelet apheresis with cell separators. Clin Lab Haematol. 1985;7(3):225-230. [PubMed: 4075737]

6. Senhauser DA, Westphal RG, Bohman JE, Neff JC. Immune system changes in cytapheresis donors. Transfusion. 1982;22(4):302-304. [PubMed: 6179266]

7. Matsui Y, Martin-Alosco S, Doenges E, et al. Effects of frequent and sustained plateletapheresis on peripheral blood mononuclear cell populations and lymphocyte functions of normal volunteer donors. Transfusion. 1986;26(5):446-452. [PubMed: 3765039]

8. Prior CR, Coghlan PJ, Hall JM, Jacobs P. In vitro study of immunologic changes in long-term cytapheresis donors. J Clin Apher. 1991;6(2):69-76. [PubMed: 1834635]

9. Richa E, Krueger P, Burgstaler EA, Bryant SC, Winters JL. The effect of double- and tripleapheresis platelet product donation on apheresis donor platelet and white blood cell counts. Transfusion. 2008;48(7):1325-1332. [PubMed: 18346017]

10. Gansner JM, Rahmani M, Jonsson AH, et al. Plateletpheresis-associated lymphopenia in frequent platelet donors. Blood. In press.;

11. Zonios DI, Falloon J, Bennett JE, et al. Idiopathic CD4+ lymphocytopenia: natural history and prognostic factors. Blood. 2008;112(2):287-294. [PubMed: 18456875] 


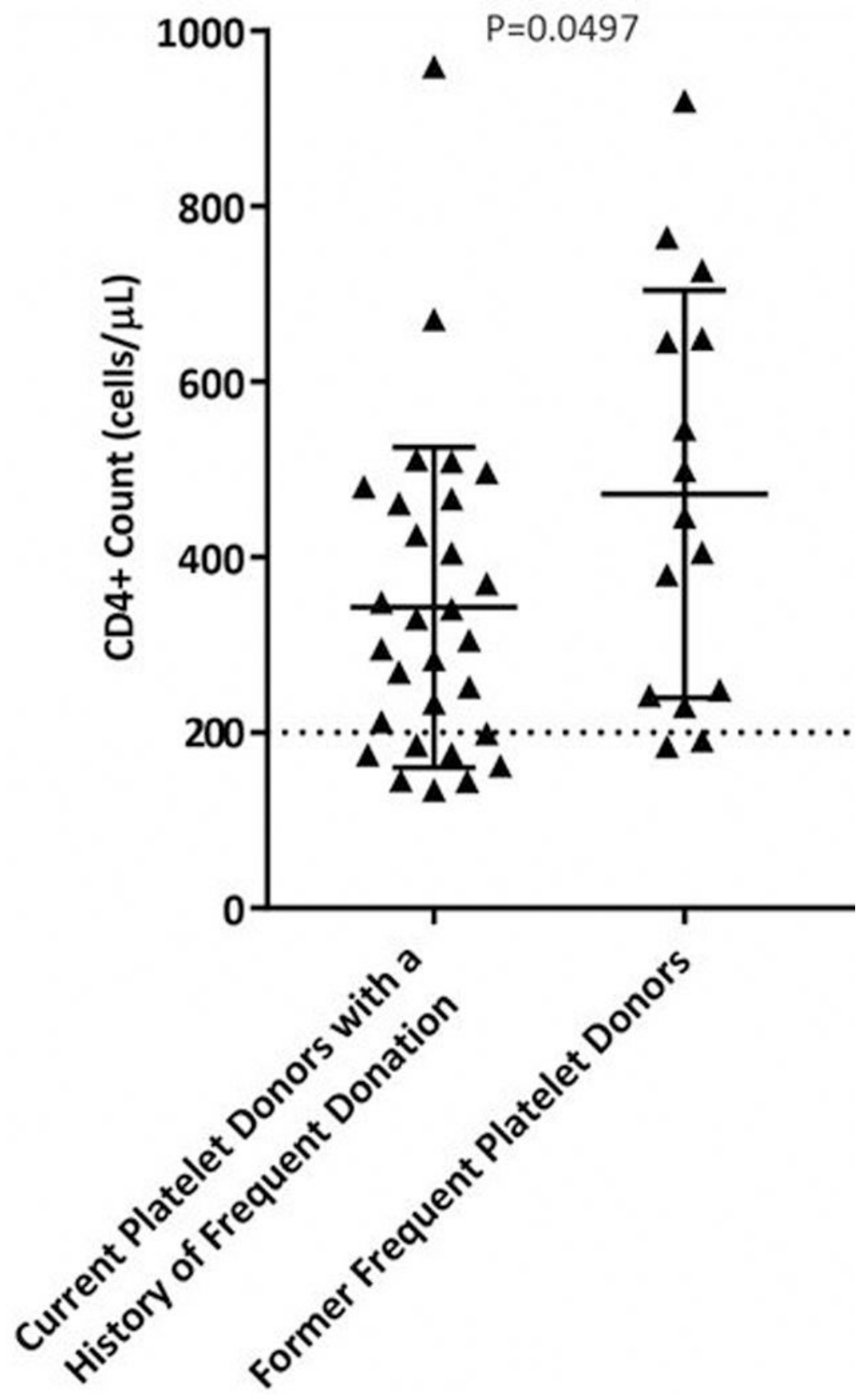

Figure 1.

Comparison of CD4+ counts between current (prior study ${ }^{10}$ ) and former (this study) platelet donors with a history of frequent plateletpheresis. Mean and standard deviation are shown. The dotted line indicates 200 cells $/ \mu \mathrm{L}$. The lower limit of the reference range is $441 \mathrm{cells} / \mu \mathrm{L}$. 


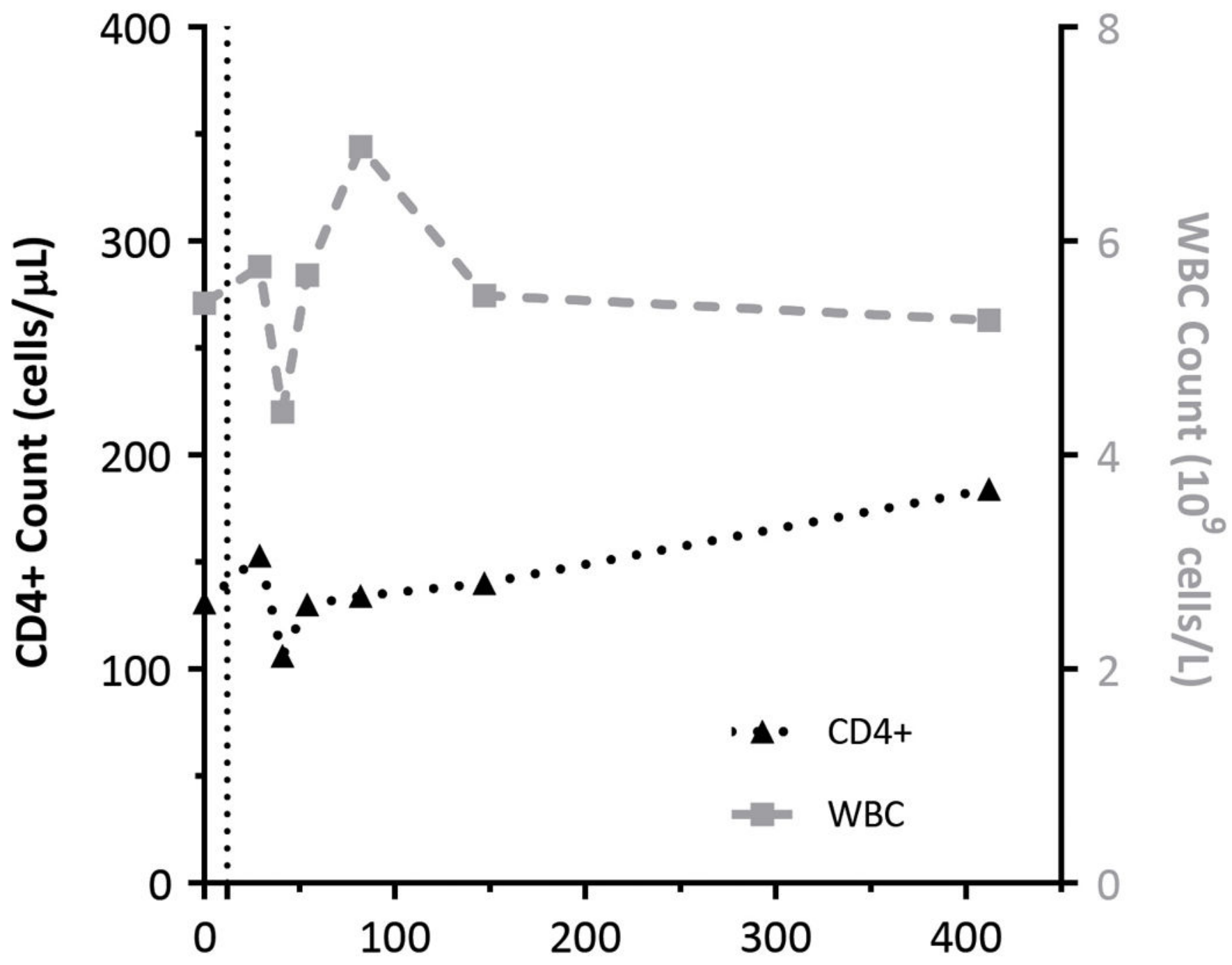

\section{Days}

Figure 2.

CD4+ and WBC counts in one former frequent apheresis platelet donor who had ceased plateletpheresis for more than 12 months. The vertical dotted line indicates the donor's last plateletpheresis session on Day 12. Participation in the current study occurred on Day 412. 
Table 1:

Characteristics and blood counts of former frequent apheresis platelet donors with a history of at least 20 plateletpheresis sessions in any 365-day period starting in 2011.

\begin{tabular}{|c|c|c|c|c|c|c|c|c|}
\hline $\begin{array}{l}\text { Donor } \\
\text { Numbe } \\
\quad \mathbf{r}\end{array}$ & $\begin{array}{c}\text { Age at } \\
\text { Study } \\
\text { Participatio } \\
\text { n (Years) }\end{array}$ & $\begin{array}{c}\mathbf{S e} \\
\mathbf{x}\end{array}$ & $\begin{array}{l}\text { Number of } \\
\text { Successful } \\
\text { Plateletpheresi } \\
\text { s Sessions in } \\
\text { the } 15 \text { Years } \\
\text { Prior to the } \\
\text { Last Donation } \\
\text { Session }\end{array}$ & $\begin{array}{c}\text { Platelet } \\
\text { Yield in } \\
\text { the } 5 \\
\text { Years } \\
\text { Prior to } \\
\text { the Last } \\
\text { Donatio } \\
\text { n } \\
\text { Session } \\
\left(\mathbf{x 1 0}^{11}\right)\end{array}$ & $\begin{array}{l}\text { Time Elapsed } \\
\text { Since } \\
\text { Plateletpheresi } \\
\text { s (Days) }\end{array}$ & $\begin{array}{l}\text { Absolute } \\
\text { Lymphocyt } \\
\text { e Count } \\
(\text { Cells } / \mu \mathrm{L})\end{array}$ & $\begin{array}{c}\text { CD4+ } \\
\text { Count } \\
(\text { Cells/ } / \mu \mathrm{L} \\
\quad)\end{array}$ & $\begin{array}{c}\text { CD8+ } \\
\text { Count } \\
(\text { Cells/ } / \mu \mathrm{L} \\
\quad)\end{array}$ \\
\hline 1 & 40 & $\mathrm{~F}$ & 47 & 306 & 593 & 1.63 & 765 & 201 \\
\hline 2 & 59 & $\mathrm{M}$ & 50 & 208 & 2387 & 1.75 & 649 & 852 \\
\hline 3 & 67 & $\mathrm{~F}$ & 77 & 542 & 658 & 1.14 & 446 & 128 \\
\hline 4 & 60 & $\mathrm{M}$ & 82 & 418 & 1344 & 1.45 & 645 & 139 \\
\hline 5 & 56 & $\mathrm{M}$ & 83 & 603 & 1768 & 1.44 & 546 & 300 \\
\hline 6 & 77 & $\mathrm{~F}$ & 93 & 228 & 731 & 0.76 & 191 & 154 \\
\hline 7 & 77 & $\mathrm{~F}$ & 112 & 207 & 647 & 0.91 & 380 & 102 \\
\hline 8 & 56 & $\mathrm{~F}$ & 138 & 609 & 579 & 1.9 & 727 & 453 \\
\hline 9 & 54 & $\mathrm{M}$ & 169 & 257 & 576 & 0.79 & 242 & 245 \\
\hline 10 & 71 & $\mathrm{M}$ & 185 & 568 & 997 & 0.68 & 230 & 53 \\
\hline 11 & 60 & $\mathrm{M}$ & 212 & 1115 & 400 & 0.98 & 184 & 220 \\
\hline 12 & 67 & $\mathrm{M}$ & 266 & 563 & 1505 & 1.78 & 920 & 477 \\
\hline 13 & 66 & $\mathrm{~F}$ & 273 & 812 & 644 & 1.31 & 499 & 166 \\
\hline 14 & 64 & $\mathrm{M}$ & 286 & 444 & 1466 & 1.49 & 405 & 281 \\
\hline 15 & 69 & M & 330 & 537 & 1120 & 1.11 & 249 & 102 \\
\hline
\end{tabular}

